Vol. 1 No. 2 Desember 2021, e-ISSN : 2807-8667| p-ISSN : 2807-8837

\title{
PENGARUH INTERNET TERHADAP MOTIVASI DAN MINAT BELAJAR PESERTA DIDIK : SURVEY PADA PESERTA DIDIK KELAS XI IPA DI SMAN 1 CIAMPEL
}

\author{
PUJIAWATI \\ Program Pasca Sarjana Pendidikan MIPA, Universitas Indrapasta PGRI Jakarta \\ E-mail: husnapujia@gmail.com
}

\begin{abstract}
ABSTRAK
Penelitian ini bertujuan untuk mengetahui adakah pengaruh internet terhadap motivasi belajar dan adakah pengaruh internet terhadap minat belajar peserta didik Kelas XI IPA di SMAN 1 Ciampel. Kegiatan penelitian ini dilakukan secara online menggunakan bantuan aplikasi google form pada bulan November 2021. Subjek penelitiannya adalah peserta didik SMAN 1 Ciampel dan sampel yang digunakan adalah peserta didik kelas XI IPA angkatan 2020. Metode penelitian pada penelitian ini adalah metode penelitian desktiptif kuantitatif. Instrumen yang digunakan adalah angket. Pengumpulan data menggunakan 3 instrumen yaitu pertama, intrumen pengaruh internet, kedua motivasi belajar peserta didik dan ketiga adalah minat belajar peserta didik. Uji coba reliabilitas instrumen didapatkan nilai Alpha Cronbah sebesar 0,880 untuk pengaruh internet, 0,915 untuk motivasi belajar dan 0,862 untuk minat belajar. Teknik analisis data yang digunakan dalam penelitian ini ialah Deskripsi data menggunakan mean sedangkan untuk faktor pengaruh menggunakan regresi. Hasil penelitian menunjukkan bahwa pengaruh media internet terhadap motivasi belajar peserta didik memiliki hubungan yang sangat kuat serta pengaruh media internet terhadap minat belajar siswa juga memiliki hubungan yang sangat kuat pula.
\end{abstract}

Kata Kunci : Internet, Motivasi Belajar, Minat Belajar

\begin{abstract}
This study aims to determine whether there is an influence of the internet on learning motivation and whether there is an influence of the internet on the learning interest of students in Class XI IPA at SMAN 1 Ciampel. This research activity was carried out online using the google form application with the address in November 2021. The research subjects were students of SMAN 1 Ciampel and the sample used was class XI IPA class 2020. The research method in this research is descriptive quantitative research method. The instrument used is a questionnaire. Collecting data using 3 instruments, namely, first, the influence of the internet, the second is students' learning motivation and the third is students' interest in learning. The reliability test of the instrument obtained Cronbah's Alpha value of 0.880 for the influence of the internet, 0.915 for learning motivation and 0.862 for interest in learning. The data analysis technique used in this study is a description of the data using the mean while for the influence factor using regression. The results showed that the influence of internet media on students' learning motivation has a very strong relationship and the influence of internet media on students' interest in learning also has a very strong relationship as well.
\end{abstract}

Keywords: Internet, Learning Motivation, Interest in Learning

\section{PENDAHULUAN}

Pendidikan adalah salah satu unsur penting dalam meningkatkan sumber daya manusia yang berkualitas dan nantinya akan berguna bagi dirinya sendiri, masyarakat, bangsa serta negara. Kualitas sumber daya manusia bergantung pada kualitas pendidikannya. Pendidikan mempunyai peran yang sangat krusial untuk membentuk masyarakat yang cerdas, damai, terbuka dan demokratis. Pendidikan menjadi titik tolak terwujudnya generasi muda agar siap bersaing di era globalisasi. Oleh karena itu, pendidikan harus selalu diperbaharui agar kualitas pendidikan suatu bangsa dapat meningkat. 
Salah satu tugas guru yang penting adalah menyampaikan ilmu atau pengalaman yang dimilikinya kepada peserta didik melalui komunikasi interaktif dalam proses belajar mengajar yang dilakukan. Kelancaran proses interaksi dan komunikasi antara guru dan peserta didik menjadi salah satu keberhasilan yang harus dicapai oleh seorang guru. Jika komunikasi tidak berjalan lancar maka akan mengakibatkan tidak tersampaikannya pesan dari guru kepada peserta didik.

Banyak sekali guru yang tidak menguasai teknik mendidik dan mengajar yang akhirnya menyebabkan peserta didik malas belajar. Menurut Winkel (dalam Arisanti dan Subhan, 2018) menyatakan bahwa pendidikan di sekolah berhasil disebabkan guru yang proaktif, kreatif dan inovasi dalam mendidik dan mengajar peserta didik di sekolah. Namun demikian fenomena yang terjadi di sekolah pada era globalisasi ini adalah banyaknya guru yang kurang berinovasi dan cenderung monoton ketika mengajar sehingga mengakibatkan motivasi dan minat belajar peserta didik rendah untuk belajar. Hasil observasi dari fenomena yang ada di Sekolah ditemukan masalah tentang motivasi dan minat belajar peserta didik yang masih rendah. Rendahnya motivasi dan minat belajar peserta didik terlihat dari beberapa hal seperti peserta didik kurang bergairah untuk mengikuti pelajaran, peserta didik tidak respon saat guru memberikan pertanyaan di kelas dan peserta didik kurang menyelesaikan tugas-tugas yang diberikan guru dan tidak mau menanyakan materi pelajaran yang belum dipahami dan rendahnya minat baca peserta didik untuk mencari tugas-tugas yang diberikan guru dengan memanfaatkan fasilitas internet.

Salah satu penemuan dan perkembangan teknologi dan informasi yang berkembang dengan sangat cepat saat ini di Indonesia adalah internet. Istilah internet ini merupakan istilah yang berasal dari bahasa Latin yakni inter yang berarti "antara". Internet merupakan kependekan dari interconnected networking atau international networking, yaitu kumpulan yang sangat luas dari jaringan komputer besar dan kecil yang saling berhubungan serta saling menghubungkan jaringan komunikasi yang ada di seluruh dunia. (Rianto, 2011). Untuk saat ini perkembangan pengguna internet di Indonesia sangatlah pesat. Menurut Menkominfo Johnny G. Plate dalam Liputan 6.com, pada awal tahun 2021 pengguna internet di Indonesia mencapai 202,6 juta jiwa. Jumlah pengguna internet ini mengalami peningkatan sebesar 15,5 persen atau sebanyak 27 juta jiwa jika dibandingkan pada Januari tahun 2020. Sedangkan untuk total jumlah penduduk Indonesia sendiri saat ini adalah kurang lebih sebanyak 274,9 juta jiwa. Dari data tersebut dapat terlihat bahwa pengguna internet di Indonesia pada awal 2021 mencapai 73,7 persen. Media internet ini menjadi salah satu kemajuan perkembangan ilmu pengetahuan dan teknologi yang dapat mendukung kebutuhan peserta didik untuk mendapatkan sumber belajar. Media internet dapat menjadi salah satu faktor yang bisa membantu peserta didik memperoleh informasi terbaru maupun fenomena yang terjadi pada saat ini yang kemudian dihubungkan dengan materi pelajaran yang disajikan oleh guru disekolah sehingga bisa termotivasi serta berminat untuk belajar. Jika Media internet ini digunakan dengan baik maka media internet ini dapat mempengaruhi serta meningkatkan pemahaman peserta didik, selain itu dapat pula dijadikan sebagai pengganti guru dalam memberikan tambahan informasi pengetahuan kepada peserta didik.

Syah (2005) dalam bukunya memaparkan bahwa pemanfaatan internet sebagai sumber belajar adalah salah satu upaya untuk membantu kegiatan prose pembelajaran agar lebih efektif karena kekayaan informasi yang tersedia di dalam internet. Selain itu internet juga dapat diakses oleh para peserta didik tanpa terbatas ruang maupun waktu artinya dimanapun mereka berada maka mereka dapat mengakses internet dengan mudah. Sehingga penggunaan media internet akan memberikan kemudahan kepada peserta didik untuk memperoleh informasi yang berhubungan dengan dunia pendidikan. Sedangkan motivasi dan minat belajar merupakan factor intern yang ada pada diri peserta didik itu sendiri untuk menunjang kegiatan pembelajaran.

Motivasi memiliki peranan dalam penguatan belajar jika peserta didik dihadapkan pada suatu masalah yang memerlukan pemecahan, dan permasalahan tersebut hanya dapat 
dipecahkan melalui bantuan hal-hal yang pernah dilaluinya atau pengalaman yang telah mereka lalui sebelumnya. Selain itu motivasi juga memiliki peranan dalam memperjelas tujuan belajar yang kaitannya sangat erat dengan kebermaknaan belajar. Peserta didik akan lebih tertarik untuk belajar sesuatu, jika yang dipelajari itu sudah diketahui manfaatnya bagi peserta didik. Jika peserta didik memiliki motivasi untuk belajar sesuatu, maka mereka akan berusaha lebih keras mempelajarinya dengan baik serta tekun, dengan harapan akhirnya mereka akan memperoleh prestasi yang baik dikemudian hari, hal ini dapat terlihat bahwa motivasi untuk belajar menyebabkan peserta didik tekun belajar. Sebaliknya, apabila peserta didik kurang atau tidak memiliki motivasi untuk belajar, maka ia tidak bisa berlama-lama ketika belajar dan lebih cepat bosan serta mereka akan lebih mudah tergoda untuk mengerjakan hal yang lain dan bukan belajar.

Minat adalah rasa suka atau rasa ketertarikan pada suatu hal atau aktivitas, tetapi tanpa adanya paksaan dari orang lain yang menyuruh. Menurut Djaali (2017), minat pada diri peserta didik tidak dibawa sejak lahir, melainkan diperoleh kemudian. Menurut Usman (2002), minat merupakan suatu sifat yang relatif menerap pada diri seseorang. Minat belajar dapat diartikan suatu rasa lebih suka ataupun kecenderungan hati kepada pelajaran, faktor minat sangatlah menentukan karena dengan adanya minat, peserta didik akan sungguh-sungguh berbuat dan bertindak serta tekun dalam mempelajari pelajaran di sekolah. Minat dapat menjadi faktor pendorong seseorang untuk mencapai keberhasilan dalam belajar.

Berdasarkan hasil penelitian yang telah dilakukan oleh Marwoto (2014) di kota Pekanbaru yang hasil penelitiannya menyatakan bahwa salah satu upaya pemecahan masalah untuk merangsang minat belajar adalah dengan cara menyediakan fasilitas belajar salah satunya adalah media internet. Internet di bidang pendidikan ini memiliki peran yang sangat penting dalam kegiatan belajar mengajar di sekolah, karena dengan internet para peserta didik dapat melengkapi ilmu pengetahuannya, sedangkan guru atau pendidik dengan adanya media internet ini mereka dapat mencari bahan ajar yang terbaru melalui internet.

Selain itu berdasarkan hasil penelitian yang telah dilakukan oleh Lestari (2012) yang memaparkan bahwa penggunaan media internet memberikan pengaruh terhadap minat belajar peserta didik, dalam penelitiannya dijelaskan bahwa media internet ini menjadikan minat belajar menjadi tinggi. Hal ini disebabkan oleh pengaruh adanya inovasi dalam proses pembelajaran dan pengajaran yang dilakukan oleh guru di sekolah.

Ketika peserta didik memiliki kemampuan untuk menggunakan internet, mereka akan dengan cepat mencari informasi yang diperlukan untuk pekerjaan rumah atau tugas lainnya. Tanpa internet tersedia, satu-satunya pilihan peserta didik memiliki adalah pergi ke perpustakaan sekolah yang mana jumlah buku-buku yang terbatas tentang beberapa mata pelajaran. Mengakses internet merupakan salah satu kegiatan yang sangat membantu peserta didik ketika mereka harus mengumpulkan berbagai sumber untuk sebuah makalah penelitian. Dengan bantuan internet peserta didik dapat menghabiskan lebih sedikit waktu untuk meneliti dan mencari serta akan mendapatkan lebih banyak waktu menyusun kertas yang ditulis dengan baik dan informatif. Bila pemanfaatan internet ini dilakukan dengan benar maka motivasi dan minat belajar peserta didikpun akan lebih tinggi. Sebaliknya, jika media internet ini tidak dimanfaatkan dengan sebaik mungkin maka motivasi dan minat belajarpun akan semakin rendah.

Namun pada kenyataan yang terjadi dilapangan khususnya di SMAN 1 Ciampel walaupun tersedia fasilitas internet di laboratorium komputer disertai dengan fasilitas wifi yang memadai serta mayoritas peserta didik juga diperbolehkan untuk membawa dan menggunakan gawai/gadget di sekolah tetapi para peserta didik kurang memanfaatkan media yang disediakan dengan sebagaimana mestinya khususnya untuk kepentingan pembelajaran. Para peserta didik lebih memilih menggunakan fasilitas internet ini untuk membuka media sosial seperti facebook ataupun game online.

Selain itu dari hasil observasi serta wawancara yang diajukan kepada beberapa guru mata pelajaran di SMAN 1 Ciampel, sebagian besar peserta didik memiliki masalah dari segi 
motivasi dan minat mereka untuk belajar. Hal ini dapat terlihat pada saat kegiatan pembelajaran sedang berlangsung di kelas, antusiasme mereka terhadap pembelajaran sangat kurang. Hal ini terlihat dari beberapa perilaku peserta didik seperti lebih sering bermain gawai/gadget, lebih banyak berbincang dengan temannya dibandingkan memperhatikan penjelasan dari guru, serta kurangnya keaktifan peserta didik dalam pembelajaran.

Berdasarkan permasalahan-permasalahan tersebut diatas, maka penulis tertari melakukan penelitian mengenai "Pengaruh Internet terhadap Motivasi dan Minat belajar peserta didik (Survey pada peserta didik kelas XI IPA di SMAN 1 Ciampel)"Penelitian ini bertujuan untuk mengetahui pengaruh internet terhadap motivasi dan minat belajar pada peserta didik khusus nya peserta didik kelas XI IPA SMAN 1 Ciampel. Penelitian ini bermanfaat untuk memberikan referensi atau hasil sebagai pelengkap penelitian atau studi yang telah dilakukan sebelumnya oleh para peneliti khususnya yang berkaitan dengan studi mengenai pemanfaatan internet. Selain itu penelitian ini diharapkan dapat memberi rmanfaat terhadap motivasi dan minat belajar di sekolah-sekolah yang memiliki jaringan internet.

\section{METODE PENELITIAN}

Penelitian ini termasuk kedalam penelitian deskriptif kuantitatif. Penelitian deskriptif kuantitatif ini brtujuan untuk melhat antara pengaruh internet terhadap motivasi dan minat belajar peserta didik. Hasil dari penelitpian ini akan diinterpretasikan menggunakan analisis deskriptif dan inferensi. Variabel bebas dalam penelitian ini adalah pengaruh media internet sedangkan variabel terikatnya yaitu motivasi dan minat belajar peserta didik.

Populasi dalam penelitian ini adalah peserta didik kelas XI IPA di SMAN 1 Ciampel sebanyak 60 orang siswa. Penelitian ini dilakukan dengan menggunakan angket/kuesioner yaitu angket pengaruh internet terhadap motivasi dan minat belajar peserta didik dengan menggunakan media online berupa google form. Angket telah di uji coba reliabilitasnya dengan didapatkan nilai alpha Cronbach. Teknik analisis data dalam penelitian ini menggunakan bantuan software SPSS 22. Deskripsi data menggunakan mean sedangkan untuk faktor pengaruh menggunakan regresi.

\section{Uji coba instrumen}

Sebelum angket/kuesioner disebar/diberikan kepada responden, maka terlebih dahulu dilakukan uji coba instrumen. Uji coba ini berfungsi untuk mengetahui validitas dan reliabilitas instrumen yang akan digunakan sehingga hasil yang diperoleh dari instrumen tersebut dapat diyakini.

Pada penelitian ini juga telah didapatkan nilai uji reliabilitas instrument penelitian dan penghitungannya dibantu dengan menggunakan software SPSS 22. Hasil uji coba instrument yang telah dianalisis menggunakan software SPSS 22 dapat dilihat pada tabel 1 di bawah ini:

Tabel 1. Hasil Uji Reliabilitas Data Penelitian

\begin{tabular}{|l|l|l|}
\hline Variabel & Cronbach's Alpha & Keterangan \\
\hline Internet $(\mathrm{X})$ & 0,880 & Reliabel \\
\hline Motivasi Belajar $\left(\mathrm{Y}_{1}\right)$ & 0,915 & Reliabel \\
\hline Minat Belajar $\left(\mathrm{Y}_{2}\right)$ & 0,862 & Reliabel \\
\hline \multicolumn{2}{r}{ Sumber : Hasil Olah Data (2021) } \\
\hline
\end{tabular}

\section{HASIL DAN PEMBAHASAN}

\section{Hasil Penelitian}

Analisis Deskriptif

Untuk melihat gambaran umum dari penelitian ini dilakukan uji analisis deskriptif yang perhitungannya dibantu dengan menggunakan software SPSS 22. Analisis deskriptif ialah metode analisis statistik yang bertujuan untuk memberikan deskripsi atau gambaran mengenai subjek penelitian berdasarkan data variabel yang diperoleh dari kelompok subjek tertentu. 
Analisis deskriptif dari penelitian yang telah dilakukan ini perhitungannya dibantu dengan menggunakan software SPSS 22 dan disajikan dalam bentuk tabel 2 seperti berikut:

Tabel 2 Descriptive Statistics

\begin{tabular}{|c|c|c|c|c|c|c|}
\hline & $\mathrm{N}$ & $\begin{array}{l}\text { Minimu } \\
\mathrm{m}\end{array}$ & $\begin{array}{l}\text { Maximu } \\
\mathrm{m}\end{array}$ & Mean & $\begin{array}{l}\text { Std. } \\
\text { Deviation }\end{array}$ & Variance \\
\hline $\begin{array}{ll}\text { Internet } & \\
\text { Motivasi } & \\
\text { Minat } & \\
\text { Valid } & \mathrm{N} \\
\text { (listwise) } & \end{array}$ & $\begin{array}{l}60 \\
60 \\
60 \\
60\end{array}$ & $\begin{array}{l}84 \\
80 \\
95\end{array}$ & $\begin{array}{l}147 \\
179 \\
158\end{array}$ & $\begin{array}{l}112,90 \\
130,00 \\
124,23\end{array}$ & $\begin{array}{l}14,026 \\
14,909 \\
11,595\end{array}$ & $\begin{array}{l}196,736 \\
222,271 \\
134,453\end{array}$ \\
\hline
\end{tabular}

Sumber : Hasil Olah Data (2021)

Berdasarkan tabelc2 diatas terlihat bahwa skor minimum dan maksimum pada variabel pengaruh internet yaitu sebesar 84 dan 147. Untuk variabel motivasi belajar skor minimum dan maksimum nya adalah sebesar 80 dan 179, sedangkan untuk minat belajar skor minimun dan maksimumnya sebesar 95 dan 158 .

\section{Analisis Inferensi}

Tujuan dari penggunaan statistik inferensi ialah untuk menjelaskan ciri-ciri yang berkaitan dengan populasi dengan menggunakan data sampel. untuk mengetahui pengaruh antara Pengaruh Internet terhadap motivasi belajar dan Pengaruh Internet terhadap minat belajar maka perlu dilihat terlebih dahulu apakah datanya linier ataukah tidak. Jika nilai signifikansi nya $>0.05$ maka dapat diinterpretasikan bahwa variabel-variabel tersebut memiliki hubungan yang linier. Setelah itu baru dilakukan uji regresi. Untuk hasil uji linieritas perhitungannya dibantu dengan menggunakan software SPSS 22 dan hasilnya dapat dilihat seperti pada tabel 3 di bawah ini:

Tabel 3 Hasil Uji Linieritas

\begin{tabular}{|c|c|c|c|c|c|c|c|c|}
\hline & & & & Sum of Squares & $\mathrm{df}$ & $\begin{array}{l}\text { Mean } \\
\text { Square }\end{array}$ & $\mathrm{F}$ & Sig. \\
\hline Motivasi & Between & (Combined) & & 10953,083 & 37 & 296,029 & 3,014 & 004 \\
\hline * Internet & Groups & Linearity & & 5280,531 & 1 & 5280,531 & 53,760 & ,000 \\
\hline & 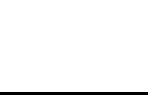 & $\begin{array}{l}\text { Deviation } \\
\text { Linearity }\end{array}$ & from & 5672,552 & 36 & 157,571 & 1,604 & ,122 \\
\hline & Within G & oups & & 2160,917 & 22 & 98,223 & & \\
\hline & Total & & & 13114,000 & 59 & & & \\
\hline Minat * & Between & (Combined) & & 5437,317 & 37 & 146,955 & 1,296 & 263 \\
\hline Internet & Groups & Linearity & & 2330,803 & 1 & 2330,803 & 20,549 & ,000 \\
\hline & . & $\begin{array}{l}\text { Deviation } \\
\text { Linearity }\end{array}$ & from & 3106,514 & 36 & 86,292 & ,761 & ,772 \\
\hline & Within G & oups & & 2495,417 & 22 & 113,428 & & \\
\hline & Total & & & 7932,733 & 59 & & & \\
\hline
\end{tabular}

Sumber : Hasil Olah Data (2021)

Berdasarkan data-data yang terlihat pada tabel 3 di atas dapat diinterpretasikan bahwa terdapat hubungan linieritas antara variabel-variabel nya. Hal ini ditunjukkan dengan nilai signifikansinya. Untuk nilai signifikansi antara variabel pengaruh internet dan motivasi belajar nilai nya sebesar $0.122>0.05$ maka dapat ditarik kesimpulan bahwa antara variabel pengaruh internet dan motivasi belajar memiliki hubungan linieritas. Sedangkan untuk nilai signifikansi antara variabel pengaruh internet terhadap minat belajar nilai nya sebesar $0.772>0.05$ maka dapat ditarik kesimpulan bahwa antara variabel pengaruh internet terhadap minat belajar memiliki hubungan linieritas. 

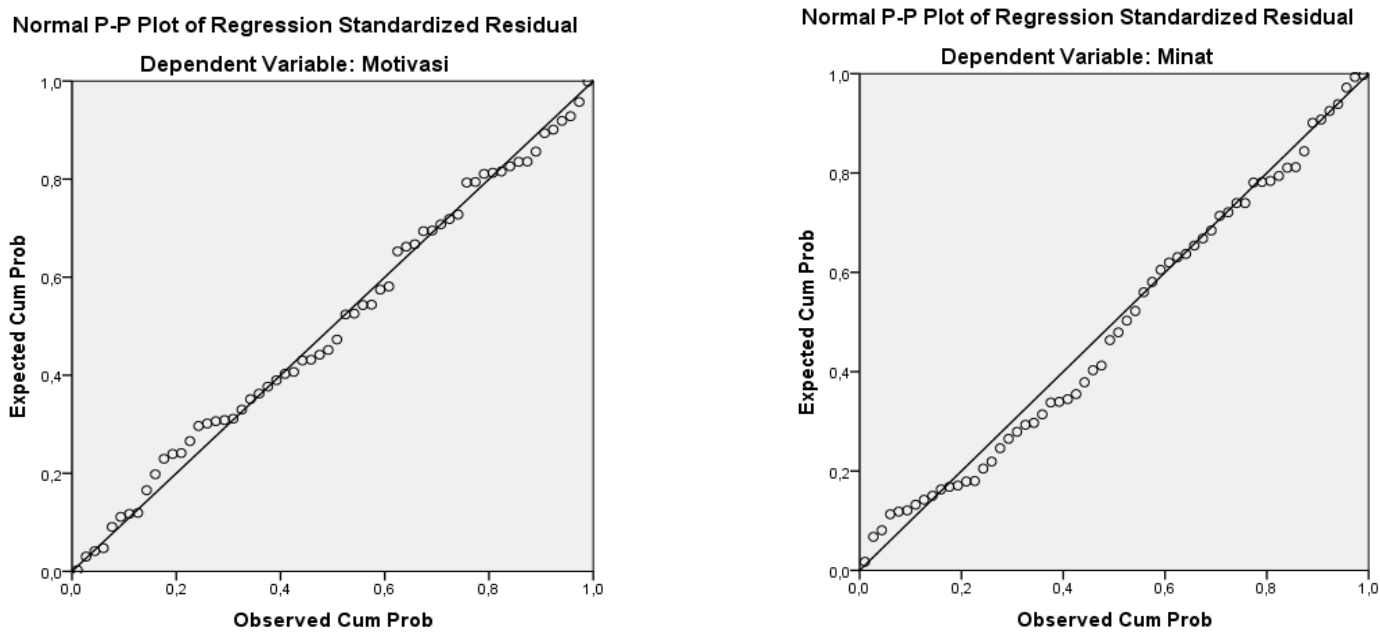

Gambar 1 Hasil Uji Normal

Pada gambar 1 diatas dapat terlihat bahwa grafik normal probability plot menunjukkan pola grafik terdistribusi normal. Data dapat dikatakan terdistribusi normal jika pada gambar plot terlihat titik-titik plot yang menyebar di sekitar garis diagonal dan penyebarannya mengikuti garis diagonalnya. Maka dapat kita simpulkan bahwa model regresi dapat digunakan untuk uji analisis selanjutnya.

Tabel 4 Hasil Uji regresi Pengaruh Internet terhadap Motivasi Belajar

\begin{tabular}{|ll|l|l|l|l|l|}
\hline \multirow{2}{*}{} & \multicolumn{3}{|l|}{ Unstandardized Coefficients } & $\begin{array}{l}\text { Standardized } \\
\text { Coefficients }\end{array}$ & & \\
\cline { 3 - 5 } & & $\mathrm{B}$ & Std. Error & Beta & t & \multirow{2}{*}{ Sig. } \\
\hline 1 & (Constant) & 53,851 & 12,270 & & 4,389 &, 000 \\
& Internet &, 674 &, 108 &, 635 & 6,253 &, 000 \\
\hline
\end{tabular}

Sumber : Hasil Olah Data (2021)

Dari data yang terlihat dari tabel 4 di atas didapatkan persamaan regresi yaitu sebagai berikut $\ddot{Y}=53,851+0.674 X$. Hasil analisis data yang didapatkan dari software SPSS 22 ini memperlihatkan bahwa koefisien regresi tersebut bernilai positif, sehingga dapat dikatakan bahwa arah pengaruh variabel pengaruh internet terhadap motivasi belajar adalah positif. Sedangkan Untuk uji koefisien determinan pengaruh internet terhadap motivasi belajar dapat dilihat pada tabel 5 di bawah ini:

Tabel 5 Hasil Uji Kekuatan antara variabel Pengaruh Internet terhadap Motivasi Belajar

\begin{tabular}{|l|l|l|l|l|}
\hline Model & R & R Square & Adjusted R Square & Std. Error of the Estimate \\
\hline 1 &, $635^{\mathrm{a}}$ &, 403 &, 392 & 11,622 \\
\hline
\end{tabular}

Sumber : Hasil Olah Data (2021)

Dari tabel 5 di atas terlihat bahwa kekuatan hubungan antara pengaruh internet terhadap motivasi belajar memiliki nilai sebesar 0.635 dapat disimpulkan bahwa kekuatan hubungan antara variabel dinyatakan kuat. Selain itu terlihat pula untuk koefisien determinan $\left(\mathrm{r}^{2}\right)$ pada tabel diatas sebesar 0,403 atau 40,3\%, sisanya sebesar 59,7\% dipengaruhi oleh faktor lain. Maka dapat kita simpulkan bahwa Internet memberikan pengaruh terhadap motivasi belajar.

Untuk hasil analisis pada variabel pengaruh internet terhadap minat belajar dapat kita lihat pada tabel 6 di bawah ini:

Tabel 6 Hasil Uji regresi Pengaruh Internet terhadap Minat Belajar

\begin{tabular}{|l|l|l|l|l|l|}
\hline \multirow{4}{*}{ Model } & \multicolumn{2}{|l|}{ Standardized } & & \\
\cline { 2 - 3 } & Unstandardized Coefficients & Coefficients & \multirow{2}{*}{ Sig. } \\
\cline { 2 - 5 }
\end{tabular}




\begin{tabular}{|ll|l|l|l|l|l|}
\hline 1 & (Constant) & 73,642 & 10,377 & & 7,097 &, 000 \\
& Internet &, 448 &, 091 &, 542 & 4,912 &, 000 \\
\hline
\end{tabular}

Sumber : Hasil Olah Data (2021)

Dari data tabel 6 di atas didapatkan persamaan regresinya yaitu sebagai berikut $\ddot{Y}=$ 73.642+0.448X. Hasil analisis data yang didapatkan dari software SPSS 22 ini memperlihatkan bahwa koefisien regresi tersebut bernilai positif, sehingga dapat dikatakan bahwa arah pengaruh variabel pengaruh internet terhadap minat belajar adalah positif. Untuk uji koefisien determinan pengaruh internet terhadap minat belajar dapat dilihat pada tabel 7 di bawah ini:

Tabel 7 Hasil Uji Kekuatan antara variabel Pengaruh Internet terhadap Minat Belajar

\begin{tabular}{|l|l|l|l|l|}
\hline Model & $\mathrm{R}$ & $\mathrm{R}$ Square & Adjusted R Square & Std. Error of the Estimate \\
\hline 1 &, $542^{\mathrm{a}}$ &, 294 &, 282 & 9,828 \\
\hline \multicolumn{4}{|c|}{ Sumber : Hasil Olah Data (2021) }
\end{tabular}

Dari tabel 7 di atas terlihat bahwa kekuatan hubungan antara pengaruh internet terhadap motivasi belajar memiliki nilai sebesar 0.542. Dapat disimpulkan bahwa kekuatan hubungan antara variabel dinyatakan kuat. Selain itu terlihat pula untuk koefisien determinan $\left(\mathrm{r}^{2}\right)$ pada tabel diatas sebesar 0,294 atau 29,4\%, sisanya sebesar 70,6\% dipengaruhi oleh faktor lain. Maka dapat disimpulkan bahwa Internet memberikan pengaruh terhadap minat belajar.

\section{Pembahasan}

\section{Pengaruh internet terhadap motivasi belajar}

Pada hasil analisis statitistik menggunakan uji regresi untuk variabel pengaruh media internet terhadap motivasi belajar siswa memperlihatkan hasil bahwa hubungan antara pengaruh internet terhadap motivasi belajar siswa nemiliki kekuatan hubungan yang kuat, hal ini diperlihatkan dengan nilai $\mathrm{R}$ sebesar 0.635 . Selain itu terlihat pula untuk koefisien determinan $\left(r^{2}\right)$ pada tabel diatas sebesar 0,403 atau $40,3 \%$, sisanya sebesar $59,7 \%$ dipengaruhi oleh faktor lain. Maka dapat ditarik kesimpulan bahwa Internet memberikan pengaruh terhadap motivasi belajar. Hal ini sesuai dengan penelitian yang dilakukan oleh Khaeriyah dan Mahmud (2017) bahwa pemanfaatan internet sebagai sumber belajar akan memediasi secara parsial yaitu disamping memiliki pengaruh tidak langsung intensitas penggunaan smartphone terhadap motivasi belajar melalui pemanfaatan internet sebagai sumber belajar, intensitas penggunaan smartphone juga mempunyai pengaruh langsung secara signifikan terhadap motivasi belajar. Selain itu berdasarkan penelitian yang telah dilakukan oleh Sahade, H. Abd. Rijal \& Anugrah Atunnisa Nur (2021) bahwa penggunaan internet dapat dimanfaatkan sebaik mungkin untuk pembelajaran dan tidak hanya digunakan untuk memanfaatkan social media saja tetapi juga media internet dapat dipergunakan sebagai salah satu media pembelajaran yang dapat meningkatkan motivasi belajar peserta didik.

Dengan adanya kemajuan teknologi informasi dan komunikasi membawa perubahan dan kemajuan diberbagai sektor terutama pada bidang pendidikan. Peranan dari teknologi informasi dan komunikasi pada bidang pendidikan sangat penting dan mampu memberikan kemudahan kepada guru dan peserta didik dalam proses pembelajaran.

Motivasi dan belajar ialah dua hal yang saling mempengaruhi satu sama lain. Belajar adalah suatu proses kegiatan yang akan mengubah tingkah laku seseorang melalui latihan atau kegiatan serta pengalaman yang dilakukan sehingga tingkah laku mereka menjadi lebih baik sebagai hasil dari penguatan yang dilandasi agar mencapai tujuan. Adapun pengertian motivasi belajar menurut Sardiman (2016:75) adalah "Keseluruhan daya penggerak didalam diri peserta didik yang menimbulkan kegiatan belajar yang menjamin kelangsungan dari kegiatan pembelajaran dan memberikan arah pada kegiatan belajar sehingga tujuan yang dikehendaki oleh subjek belajar itu dapat tercapai”. Motivasi belajar dalam diri seseorang akan merangsang semangat dalam belajar. Dalam motivasi belajar terkandung usaha untuk mencapai tujuan 
belajar yaitu pemahaman terhadap materi dan pengembangan proses belajar. Selain itu, motivasi belajar ini juga menjadi sebuah penggerak atau pendorong yang dapat memberikan seseorang memiliki ketertarikan kepada belajar sehingga mereka akan belajar secara terusmenerus.

Motivasi belajar merupakan daya penggerak yang didapatkan dari dalam diri seseorang yang dapat memberikan dorongan kepada peserta didik untuk melakukan kegiatan belajar sehingga mereka dapat menambah pengetahuan juga keterampilan serta pengalaman mereka. Motivasi belajar ini dapat tumbuh karena adanya keinginan agar mampu mengetahui dan memahamu sesuatu serta mendorong dan menggerakkan minat belajar peserta didik sehingga mereka dapat bersungguh-sungguh belajar dan termotivasi untuk menggapai motivasi.

Dalam kegiatan belajar mengajar, motivasi sangatlah dibutuhkan untuk membangkitkan gairah dan semangat belajar peserta didik sehingga kegiatan pembelajaran dapat berjalan dengan baik dan dapat mencapai tujuan yang diinginkan. Ketika motivasi belajar seorang peserta didik rendah maka dapat menimbulkan dampak negatif bagi peserta didik tersebut. Motivasi belajar yang cenderung rendah dapat mengakibatka rendahnya keberhasilan dalam belajar sehingga pada akhirnya prestasi belajar peserta didik akan menjadi rendah pula. Motivasi belajar dalam diri peserta didik satu dengan yang lain berbeda, beberapa peserta didik ada yang memiliki motivasi belajar tinggi tetapi adapula peserta didik yang memiliki motivasi belajar rendah.

\section{Pengaruh internet terhadap minat belajar}

Pada hasil analisis statitistik menggunakan uji regresi untuk variabel pengaruh media internet terhadap minat belajar siswa memperlihatkan hasil bahwa hubungan antara pengaruh internet terhadap motivasi belajar siswa nemiliki kekuatan hubungan yang kuat, hal ini diperlihatkan dengan nilai $\mathrm{R}$ sebesar 0.542. dari nilai tersebut dapat terlihat bahwa kekuatan hubungan antara variabel dinyatakan kuat. Selain itu terlihat pula untuk koefisien determinan $\left(\mathrm{r}^{2}\right)$ pada tabel diatas sebesar 0,294 atau 29,4\%, sisanya sebesar 70,6\% dipengaruhi oleh faktor lain. Maka dapat disimpulkan bahwa Internet memberikan pengaruh terhadap minat belajar. Hal ini sesuai dengan penelitian yang dilakukan oleh Arisanti \& Subhan (2018) bahwa pengaruh media internet terhadap minat belajar siswa memiliki pengaruh yang tinggi. Selain itu penelitian lain yang dilakukan oleh Nasution (2021) menunjukkan bahwa penggunaan internet memberikan pengaruh yang signifikan terhadap minat belajar PAI remaja di Kelurahan Pijorkoling Kecamatan Padangsidimpuan Tenggara.

Minat belajar merupakan sikap ketaatan dalam kegiatan proses belajar, ketaatan ini baik yang menyangkut perencanaan jadwal belajar yang mereka miliki maupun inisiatif dirinya sendiri untuk melakukan usaha untuk lebih bersunggguh-sungguh dalam belajar (Andriani dan Rasto,2019). Menurut Azhar (2009) mengemukakan bahwa siswa yang memiliki minat belajar tinggi akan belajar dengan kesadaran yang ada dalam diri sendiri atau dengan kata lain tidak adanya paksaan dari pihak lain. Berdasarkan analisa dan pendapat-pendapat penelitian diatas maka dapat diinterpretasikan bahwa pemanfaatan internet sebagai sumber belajar dan minat belajar yang tinggi dapat meningkatkan prestasi belajar hal ini diakibatkan karena semakin banyak siswa yang mengakses internet sebagai sumber belajar.

Berdasarkan beberapa pendapat ahli dan penelitian-penelitian yang telah dilakukan dapat ditarik kesimpulan bahwa pemanfaatan media internet sebagai sumber belajar serta diiringi minat belajar yang tinggi dapat meningkatkan prestasi belajar, karena dengan semakin banyaknya peserta didik yang mengakses internet sebagai sumber untuk belajar makan akan semakin meningkat pula minat belajar peserta didik tersebut.

Minat belajar ialah sikap ketaatan dalam kegiatan proses belajar mengajar, baik yang menyangkut perencanaan jadwal belajar yang mereka miliki maupun inisiatif dirinya sendiri untuk melakukan suatu usaha tersebut dengan bersunggguh-sungguh dalam belajar (Andriani dan Rasto, 2019). Minat belajar ialah kemampuan yang disertai perhatian serta keaktifan yang disengaja, dan pada akhirnya akan melahirkan rasa senang sehingga dari situ lah akan muncul 
perubahan perilaku, baik berupa pengetahuan, sikap dan keterampilan berdasarkan pengalaman dan interaksi dengan lingkungan.

\section{KESIMPULAN}

Berdasarkan hasil analisis yang telah dilakukan oleh peneliti didapatkan kesimpulan bahwa media internet memiliki pengaruh terhadap motivasi belajar siswa, selain itu media internet ini juga memiliki pengaruh terhadap minat belajar siswa. Analisis kajian yang terlihat memiliki makna bagi peserta didik bahwa media internet ini memiliki pengaruh positif bagi peserta didik. Selain itu diperlihatkan pula bahwa media internet ini memiliki hubungan yang kuat baik dengan motivasi maupun minat belajar peserta didik. Dengan meningkatnya motivasi dan minat peserta didik ini diharapkan prestasi yang nantinya akan didapat oleh siswapun meningkat. Akhirnya dapat diambil kesimpulan bahwa pengaruh media internet terhadap motivasi belajar peserta didik memiliki hubungan yang kuat serta pengaruh media internet terhadap minat belajar siswa juga memiliki hubungan yang kuat pula.

\section{DAFTAR PUSTAKA}

Andriani, R., \& Rasto, R. (2019). Motivasi belajar sebagai determinan hasil belajar peserta didik. Jurnal Pendidikan Manajemen Perkantoran, Vol. 4 No. 1, Hal. 80-86, From doi: https://doi.org/10.17509/jpm.v4i1.14958

Arisanti, D., \& Subhan, M. (2018). Pengaruh Penggunaan media Internet Terhadap Minat Belajar Peserta didik Muslim di SMP Kota Pekanbaru. Jurnal Al-Thariqah. Vol. 3 No.2, from doi: https://doi.org/10.25299/althariqah.2018.vol3(2).2322

Arsyad, Azhar. 2009. Media Pembelajara, Jakarta: Grafindo Persada.

Djaali, Psikologi Pendidikan, Jakarta: PT Bumi Aksara, 2017, cet. 10.

Irsan, Kahar. 2018. Pengaruh Motivasi dan Minat Belajar Siswa Kelas X terhadap Hasil Belajar Servis Atas Bola Voli SMA Negeri 18 Luwu. Doctoral Dissertation. Universitas Negeri Malang. Malang

Khaeriyah., \& Mahmud, A. (2017). Pengaruh Intensitas Penggunaan Smartphone dan Pemanfaatan Internet terhadap Motivasi Belajar dan Hasil Belajar Ekonomi. Economic $\begin{array}{lllll}\text { Education Analysis } & \text { Journal. } & 6 & \text { (1), from }\end{array}$ https://journal.unnes.ac.id/sju/index.php/eeaj/article/view/13480

Maidiana. (2021). Penelitian Survey. ALACRITY : Journal Of Education, Vol. 1, from http://lpppipublishing.com/index.php/alacrity

Marwoto. "Strategi Guru Sejarah Dalam Meningkatkan Minat Belajar Peserta didik Pada Mata Pelajaran Sejarah Di Sman 10 Pekanbaru." Jurnal Lentera 5.14 (2014), from doi: https://lentera.ejournal.unri.ac.id/index.php/JSBS/article/view/2822

Nasution, Anggi T. (2021). Pengaruh Penggunaan Internet terhadap Minat Belajar PAI Remaja di Kelurahan Pijorkoling Kecamatan Padangsidimpuan Tenggara. Skripsi. Fakultas Tarbiyah dan Ilmu Keguruan Insvtitus Agama Islam Negeri Padangsidimpuan. Padangsidimpuan.

Prima Lestari., S. 2012. Pengaruh penggunaan media internet terhadap prestasi belajar ekonomi Peserta didik Kelas XII IPS SMA SWASTA BERSAMA BERASTAGI TA. 2011/2012. Skripsi. Fakultas Ekonomi Universitas Negeri Medan. Medan.

Rianto, 2011, Teknologi Informasi Pendidikan, Penerbit Gava Media, Yogyakarta

Rivai, Immawati NA. (2021). Pengaruh Pembelajaran Online Terhadap Motivasi Belajar dan Minat Belajar Mahasiswa PGMI di Tengah Pandemi Covid-19. Jurnal Riset $\begin{array}{lllll}\text { Pendidikan } & \text { Dasar, } & 04 & \text { (2) hal, } 168-179, & \text { from }\end{array}$ http://journal.unismuh.ac.id/index.php/jrpd

Sahade, Rijal, H. Abd., \& Nur, A. A. (2021). Pengaruh Penggunaan Media Internet terhadap Motivasi Belajar Siswa Program Keahlian Akuntansi di SMK Negeri 1 Makassar. Klasikal: Journal of Education, Language Teaching and Science, 3(2). doi: https://doi.org/10.52208/klasikal.v3i2.98 
Sardiman AM. 2016. Interaksi dan Motivasi Belajar Mengajar, Jakarta: Rajawali Press Slameto. 2003. Belajar dan Faktor- Faktor yang Mempengaruhi, Jakarta: Renika Syah, Muhibbin. 2005. Psikologi Penelitian Suatu Pendekatan Baru. Bandung: Remaja Rosdakarya.

Usman, Moh. Uzer, Menjadi Guru Profesional, Bandung: PT Remaja Rosdakarya, 2002, cet. 14. 